\title{
LUT
}

University

Rapid multinationalization: Propositions for studying born micromultinationals

\author{
Vanninen Heini, Kuivalainen Olli, Ciravegna Luciano
}

This is a Final draft

version of a publication

published by Elsevier

in International Business Review

DOI: $\quad 10.1016 /$ j.ibusrev.2016.09.005

Copyright of the original publication: () 2016 Elsevier Ltd.

Please cite the publication as follows:

Vanninen Heini, Kuivalainen Olli, Ciravegna Luciano (2016), "Rapid multinationalization:

Propositions for studying born micromultinationals", International Business Review, vol. 26, iss. 2, p. 365-379. (DOI: 10.1016/j.ibusrev.2016.09.005).

This is a parallel published version of an original publication.

This version can differ from the original published article. 


\section{Rapid multinationalization: Propositions for studying born micromultinationals}

\section{Heini Vanninen • Olli Kuivalainen • Luciano Ciravegna}

\section{This is an Author's Original Manuscript (AAM) of an article published by Elsevier in International Business Review. Please cite the published article:}

Vanninen Heini, Kuivalainen Olli, Ciravegna Luciano (2016), "Rapid multinationalization: Propositions for studying born micromultinationals”, International Business Review, Early view, in press. (DOI: 10.1016/j.ibusrev.2016.09.005).

http://dx.doi.org/10.1016/j.ibusrev.2016.09.005

\section{Authors}

${ }^{1}$ Heini Vanninen School of Business and Management, Lappeenranta University of Technology

School of Business and Management, Lappeenranta University of Technology PL 20, 53850 Lappeenranta, Finland heini.vanninen@lut.fi

Olli Kuivalainen School of Business and Management, Lappeenranta University of Technology and The University of Manchester, Alliance Manchester Business School

School of Business and Management, Lappeenranta University of Technology PL 20, 53850 Lappeenranta, Finland olli.kuivalainen@lut.fi

The University of Manchester, Alliance Manchester Business School, Booth St W, Manchester M15 6PB, United Kingdom olli.kuivalainen@manchester.ac.uk

Luciano Ciravegna King's College, University of London King's College, University of London Strand, London, WCC2R 2LS, United Kingdom luciano.ciravegna@incae.edu

${ }_{1}$ The authors contributed equally to this study 


\title{
Rapid multinationalization: Propositions for studying born micromultinationals
}

\begin{abstract}
This study examines how so-called born micromultinationals multinationalize. Existing theoretical frameworks do not capture the multinationalization of young and small firms because of the literature gap separating studies on born globals and international new ventures from the research on multinational enterprises. However, firms go beyond accelerated internationalization and engage in accelerated multinationalization. Born micromultinationals invest and operate in multiple countries from, or soon after, their foundation. We argue that it is necessary to examine their smallness, newness and entrepreneurial nature, as suggested in the BG/INV literature, as well as to investigate why and how they invest abroad through the lenses of MNE theories. We discuss existing theories and examine them in the light of four case studies of Finnish born micromultinationals. Our results show that the organizational, locational and internalization approach and transaction costs economics for example, have explanatory power for the FDIs conducted by born micromultinationals. We suggest that the multinationalization process of born mMNEs consists of commitment decisions; reconfigurations of the value chain; and learning from, and creating and building trust with internal sources.
\end{abstract}

Keywords: Micromultinationals, Born Micromultinationals, Internationalization, Multinationalization, International New Ventures, Born Globals, Networks, International Strategy 


\section{INTRODUCTION}

Multinational companies of the $21^{\text {st }}$ century are not necessarily large. At little or no cost, even the smallest business has access to communications and computing innovations that were beyond their reach just a decade ago (Subramaniam, 2015). SMEs that operate like multinational enterprises in using high-commitment modes of entering foreign markets are called micromultinationals (mMNEs) (Coviello, 2015; Dimitratos, Johnson, Slow \& Young, 2003), which, by combining virtual and physical networks, have the potential to disrupt industries (Subramaniam, 2015). An example of an mMNE is the Australian cloud-based business-management software provider WORK[etc] (www.worketc.com). This young firm has 22 employees in five countries and eight locations.

Why are these companies important? For one thing, mMNEs enjoy advantages that are unavailable to SMEs operating in a single market, such as being able to benefit from global variations in knowledge, skills and labour costs (Varian, 2011). They can conduct their business around the world and around the clock across multiple time zones (ibid.). Many of them operate in industries in which the products are intangible and thus easily transferable, such as the software domain.

In our study we focus on born mMNEs, i.e. mMNEs that started international operations soon after their foundation. We have formulated the following research question to guide this study: How do born mMNEs multinationalize? A multinational enterprise (MNE) is, by definition, an enterprise that owns and controls value-adding activities in two or more countries (Dunning, 1989). Accordingly, multinationalization in this study is viewed as the process of becoming and further developing as a multinational company. In our opinion, a 
company becomes multinational (from an international, export-based company) at the moment of its first foreign direct investment (FDI). However, this is not the end of the process but marks the beginning of real multinationalization. Studies that concentrate on born globals (BGs) and international new ventures (INVs) tend to refer to this process as a 'pattern' or 'pathway' of internationalization. Kuivalainen et al. (2007), for instance, describe the key dimensions of this process as scale (export intensity, i.e. the share of turnover from foreign markets), scope (the number of markets in which the company sells) and time (the speed of internationalization) and ignore multinational properties such as establishing FDIs. Thus, we believe it is justified to differentiate accelerated multinationalization from accelerated internationalization (Weerawardena, Sullivan, Liesch \& Knight, 2007) given our focus on how the process of establishing FDIs proceeds, rather than merely focussing on the scale, scope and time aspects that characterize studies of the internationalization process. Firms establishing FDIs, and thus engaging in multinationalization, face different challenges from those confronting exporting firms because they need to think about aspects - such as HR strategy and knowledge transfer - from different perspectives. Internationalization may merely entail exporting without any of the challenges of a multinational company. Multinational firms need to optimize their business in terms of its configuration, the design and redesign of the value chain and its coordination, creating a system for adjusting the roles and functions of interdependent units (Vahlne, Ivarsson \& Johanson, 2011).

As a starting point we examine the multinationalization process of born mMNEs, as depicted in the literature on international business, and derive our ex-ante explanatory factors from both the BG/INV literature and traditional IB theories, such as the resource-based view (RBV) and transaction cost economics (TCE). Multinationalization has been studied extensively on the MNE level (e.g. Andersson \& Forsgren, 1996; Andersson, Forsgren \& 
Holm, 2001; Birkinshaw \& Hood, 1998), but it remains unclear how the process evolves in smaller companies (Dimitratos et al., 2014). These firms have not been examined through the theoretical lenses of MNE theories that extend beyond the speed and scope of rapid internationalization.

Born mMNEs are not similar to the exporting BGs and INVs discussed in the earlier literature (McDougall \& Oviatt, 2000; Oviatt et al., 1995; Shrader et al., 2000) and rapidly transform into MNEs, opening different types of subsidiaries in multiple locations at a very early stage (Dimitratos et al., 2003). Although firms that internationalize early and rapidly after their foundation, such as BGs and INVs (Oviatt, McDougall \& Loper, 1995; Shrader et al., 2000), have been a strong focus of academic study in recent decades, it is assumed in most of the research that such firms serve international markets through lower-commitment modes of investment (e.g. Jones, 1999; Ripollés, Blesa \& Monferrer, 2012; Brouthers \& Hennart 2007; Brouthers \& Nakos 2004): the idea that SMEs can also internationalize (several) parts of their value chain has been largely neglected since Oviatt and McDougall's (1994) seminal INV study was published (Kuivalainen, Sundqvist \& Servais, 2007). However, as the economy has shifted away from physical goods towards the production of information, SMEs have more options for organizing their operations (Child \& McGrath, 2001). As Cavusgil and Knight (2015: 13) point out in the Journal of International Business Studies retrospective, 'in the longer term, as technology facilitates global, virtual small firms that configure and coordinate their value chains with the aid of iPads, iPhones, and similar devices, we may reach a point where the born global concept becomes outmoded. -- Research must keep pace with the evolving patterns of start-up firms.' There have also been calls for more research focusing on younger SMEs and their choice of foreign-market entry mode (Laufs \& Schwens, 2014). The entry modes that young SMEs adopt to penetrate foreign 
markets affect their future success (Burgel \& Murray, 2000; Dhanaraj \& Beamish, 2003). In connection to this, mMNEs may exert more control over international activities and thereby realize superior performance (Dimitratos, Amorós, Etchebarne \& Felzensztein, 2014; Prashantham, 2011) and thus deserve more research attention. Furthermore, the assumption that SMEs only use low-commitment modes may limit the types of support that governments give them. There are costs and challenges that mMNEs face that SMEs focusing on exports do not (Contractor, Kumar, Kundu \& Pedersen, 2010), and it would therefore be beneficial to enhance understanding of them. We argue that making sense of this phenomenon could help in guiding managers and better framing policy debates. This is important as SMEs' multinationalization has an effect on the global economy and culture (Varian, 2011). Given mMNEs increasing importance on a global scale, this is an avenue that merits further investigation (Dimitratos et al., 2014).

In our empirical study we scrutinize the suitability of the existing literature in the light of findings derived from four case studies of Finnish born mMNEs. Our contribution to the literature is twofold. First, we provide empirical explanations related to the process of multinationalization in firms of this type, which are even more extreme in their internationalization than BGs. Second, iterating the theory and case studies, we develop a set of propositions to characterize born mMNEs. We conclude that the multinationalization process of born mMNEs consists of commitment decisions; reconfigurations of the value chain; and learning from, and creating and building trust with internal sources.

\section{THEORETICAL BACKGROUND}




\subsection{Born mMNEs}

SMEs that own or control value-adding activities in two or more countries are mMNEs (Dimitratos et al., 2003). We note that this is a simplistic measure but after the first FDI a mMNE needs to start to learn how to do local HRM in the host country for example: in general, many aspects related to the common tasks and duties prevalent among MNEs come to the fore and it can be said that these firms operate like multinationals.

Although the term multinational was used earlier to describe the international activities of large firms (Dunning, 1989), cases of SMEs using more advanced entry modes have been reported regularly (Dimitratos et al., 2003). As Mathews and Zander note in their JIBS article (2007), mMNEs constitute a new MNE species in the global economy. Although not all mMNEs are INVs, and vice versa, some do establish their foreign operations soon after their foundation, thereby qualifying as INVs (McDougall \& Oviatt, 1996; Zahra, Ireland \& Hitt, 2000) and in some cases as BGs (Knight, Madsen \& Servais, 2004) regarding their time to internationalization if they have established these operations in less than three years from their inception. We use the term born mMNEs (Dimitratos et al., 2003) to describe firms that, despite being small and resource-constrained SMEs, own or control value-adding activities (they have established FDIs) in two or more countries in less than three years after their foundation. In Oviatt and McDougall's (1994) seminal paper, they presented four types of INV based on two dimensions, value-chain activities (few-many) and the number of countries (few-many). In fact their global start-ups, which would score high values on both dimensions, could be considered similar to born mMNEs. However, even though a global start-up is the most committed manifestation of an INV, it merely has close network alliances in multiple countries (Oviatt \& McDougall, 1994) and is thus different from born mMNEs 
that go beyond this networked approach and establish their own FDIs at an early stage (see Figure I for the positioning of born mMNEs).

Figure I. The positioning the born mMNE

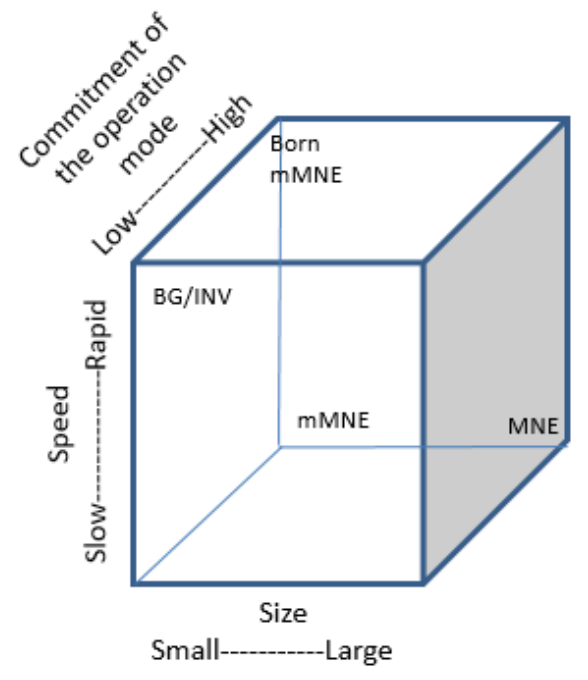

There is scant empirical evidence on mMNEs' activities but some evidence exists that the utilization of a high-commitment operation mode often coincides with strong co-operation, even with competitors (Dimitratos et al., 2016). Early and rapid internationalization is often based on networking and social capital (Dimitratos et al., 2014; Prashantham, 2011) and hence born mMNEs indeed often combine elements from INVs and traditional MNEs, supporting our definition.

\subsection{The multinationalization process}

We refer to the multinationalization process as the progression of events in an organizational entity’s existence over time as it follows its pathway to becoming and developing as a multinational company. Multinationalization, in the context of born mMNEs, can also be seen as a process, in this case a very rapid one, that could be examined through the lenses of process models. Given our aim to investigate how born mMNEs multinationalize, we decided 
to focus on one of the classic models of the internationalization process, the Uppsala model (e.g. Johanson \& Vahlne, 1977), as a starting point for our analysis. We use it here a priori as an internationalization process model, not as a contradictory view on rapid internationalization as it is commonly seen in other studies: in this we follow Hashai \& Almor (2004), for example, who have already pointed out that BG firms may follow an accelerated internationalization process, but it is still a process.

A key concept in a process is change. Change, which is one type of event, is described as the empirical observation of difference in form, quality or state over time in an organizational entity (Van de Ven \& Poole, 1995). This is depicted in the Uppsala internationalization process model for example. The original Uppsala model describes the internationalization process of a firm that suffers from the liability of foreignness: through commitments, decisions and knowledge development it slowly overcomes this liability (Johanson \& Vahlne, 1977). Companies may also suffer from the liability of outsidership, lacking not only market knowledge but also knowledge about business opportunities (Johanson \& Vahlne, 2009). Knowledge may be acquired externally with or from partners, or internally with or from subsidiaries. Learning about the activities of the subsidiary and its local network, and building trust require interacting with key people in the subsidiary (Vahlne, Schweizer \& Johanson, 2012). The Uppsala model has also been applied to the globalization process (Vahlne et al., 2011) in which decisions focus on reconfiguring the value chain and redesigning the coordination mechanisms. Following this lead we suggest that in the born mMNE context a key change variable in the multinationalization process is the commitment decision related to the reconfiguration of the value chain. The following section explores how salient literature streams in international business could explain how born mMNEs multinationalize. 


\subsection{Multinationalization in the literature}

The multinationalization of SMEs is best understood through the integration of several literature streams and theoretical perspectives (Coviello \& McAuley, 1999). We believe that integrating different perspectives potentially enriches the analysis, especially given our focus on a yet under-examined type of internationalization, i.e. the multinationalization of born mMNEs. However, in line with Van de Ven and Poole (1995), we find it important to preserve the distinctiveness of the perspectives and literature streams we integrate, which is possible because they provide alternative interpretations that complement but do not nullify each other (Van de Ven \& Poole, 1995). Thus, in this study we examine the process of multinationalization in born mMNEs through the alternative lenses of common theories and literature streams that are used to explain the speed, intensity and scope of internationalization - which in our context can be seen as dimensions that create an entity that we could call the degree of multinationalization (see Table I). In other words, we consider the explanatory factors with regard to when, how and where born mMNEs multinationalize. By internationalization speed we mean the time lag between inception and the first entry into a foreign market, which is a common criterion to distinguish INVs and BGs from the companies following a more conservative and traditional internationalization pathway (cf. e.g. Acedo \& Jones, 2007; Prashantham \& Young, 2011). With the scope of internationalization, common measures relate to the choice of the location of firms' value chain activities. For the purposes of this study we focus on entry (or operation) mode as an intensity measure. In the BG literature entry mode has not been a key variable. Instead, export intensity or foreign-sales-to-total-sales ratios have been used (for examples, see e.g. Knight et al., 2004; Kuivalainen et al., 2007). This type of operationalization often stems 
from the fact that most INVs and BGs are exporters. However, several firms internationalize early through higher-commitment entry modes rather than exports.

Different streams of international business literature have emphasized numerous explanatory factors for entry or operation mode. In Table I and in the following paragraphs we highlight the explanations that we consider important on the basis of our literature review. These factors are not exclusive, and we believe that all these viewpoints are needed to explain the whole process of rapid expansion to international markets among SMEs and eventually their multinationalization. Although the usual explanations tend to rely on the BG/INV and network literature we have also considered classic theories and frameworks to explain FDI, i.e. transaction cost economics (TCE), the organizational, locational and internalization (OLI) model, RBVs and knowledge-based views. There is limited knowledge on e.g. the OLI approach and transaction cost-based explanations and their fit within the mMNE literature and even among SMEs in general.

Table I: Theories and literature explaining the multinationalization of born mMNEs

\begin{tabular}{|l|l|l|}
\hline LITERATURE & $\begin{array}{l}\text { THE FOCAL } \\
\text { DIMENSIONS OF } \\
\text { MULTINATIONALIZ- } \\
\text { ATION }\end{array}$ & THE FINDINGS MAIN EXPLANATORY FACTORS \\
\hline The RBV & $\begin{array}{l}\text { Internationalization } \\
\text { speed* }\end{array}$ & Linked to a firm's resource endowments \\
$\begin{array}{l}\text { Rugman, Verbeke \& } \\
\text { Nguyen, 2011; Peng, 2001); } \\
\text { ff. Johanson \& Vahlne } \\
\text { (1977). }\end{array}$ & $\begin{array}{l}\text { Entry mode } \\
\text { internationalization } \\
\text { scope }\end{array}$ & $\begin{array}{l}\text { Linked to the resources a firm can mobilize to enter markets } \\
\text { Gradual; linked to resource accumulation }\end{array}$ \\
\hline $\begin{array}{l}\text { Studies of young } \\
\text { international firms, } \\
\text { BGs/INVs }\end{array}$ & $\begin{array}{l}\text { Internationalization } \\
\text { speed }\end{array}$ & $\begin{array}{l}\text { The fast proactive targeting of global markets and also } \\
\text { reactive, exploiting unexpected opportunities. The skills, } \\
\text { (Jones, 1999; McDougall \& } \\
\text { Oviatt, 2000; Shrader et al., }\end{array}$
\end{tabular}




\begin{tabular}{|c|c|c|}
\hline $\begin{array}{l}\text { 2000; Bell, Crick \& Young, } \\
\text { 2004; Kuivalainen et al., } \\
\text { 2007; Lopez, Kundu \& } \\
\text { Ciravegna, 2008) }\end{array}$ & $\begin{array}{l}\text { Location or } \\
\text { internationalization } \\
\text { scope }\end{array}$ & $\begin{array}{l}\text { modes, such as exporting } \\
\text { Linked to entrepreneurial characteristics and resources, } \\
\text { including networks, as well as serendipity. The niche } \\
\text { markets the firm wishes to target. }\end{array}$ \\
\hline $\begin{array}{l}\text { Relational (network) } \\
\text { perspective } \\
\text { (Gulati, Nohria \& Zaheer, } \\
\text { 2000; Coviello, 2006; } \\
\text { Coviello \& Munro, 1997; } \\
\text { Ciravegna, Lopez \& Kundu, } \\
\text { 2013; O’Farrell \& Wood, } \\
\text { 1994; Nummela, Saarenketo } \\
\text { \& Puumalainen, 2004) }\end{array}$ & $\begin{array}{l}\text { Internationalization } \\
\text { speed } \\
\text { Entry mode } \\
\text { Location or } \\
\text { internationalization } \\
\text { scope }\end{array}$ & $\begin{array}{l}\text { Networks and client followership influence } \\
\text { internationalization speed } \\
\text { The entry mode depends on relationships with clients and } \\
\text { suppliers. FDI near clients in order to establish and maintain } \\
\text { relations with foreign clients (client followership). } \\
\text { The location choice depends on networks - firms follow } \\
\text { their clients, suppliers and partners }\end{array}$ \\
\hline $\begin{array}{l}\text { TCE } \\
\text { (Hennart \& Park, 1994, } \\
\text { Hennart, 2009; Rugman \& } \\
\text { Verbeke, 2003); cf. Dunning } \\
\text { (1998). }\end{array}$ & $\begin{array}{l}\text { Location or } \\
\text { internationalization } \\
\text { scope }\end{array}$ & $\begin{array}{l}\text { The entry mode is determined by the best mechanisms to } \\
\text { control opportunism } \\
\text { Via exports when contractual rules are sufficient to govern } \\
\text { transactions, via FDI when opportunism may be more likely } \\
\text { The main focus is on the decision whether to produce at } \\
\text { home or abroad (the location decision); the optimal location } \\
\text { depends on aspects such as plant economies of scale, } \\
\text { transportation costs (how to minimize them by being within } \\
\text { a spatial cluster), trade barriers and the presence of long- } \\
\text { standing customers }\end{array}$ \\
\hline $\begin{array}{l}\text { OLI Model (Aharoni, 1993; } \\
\text { Dunning, 1993, 1998; } \\
\text { Brouthers, Brouthers \& } \\
\text { Werner, 1996); cf. Hennart } \\
\text { (2009). }\end{array}$ & $\begin{array}{l}\text { Entry mode } \\
\text { Location or } \\
\text { internationalization } \\
\text { scope }\end{array}$ & $\begin{array}{l}\text { The entry mode depends on the determinants of } \\
\text { internationalization (whether it is market seeking, efficiency } \\
\text { seeking, resource seeking or strategic-asset seeking), the } \\
\text { features of the home base and target markets, and the } \\
\text { existence of organizational and internalization (firm- } \\
\text { specific) advantages as well as locational (country-specific) } \\
\text { advantages } \\
\text { Organizational advantages can be exploited in the chosen } \\
\text { location, locational advantages include adding value to the } \\
\text { firm’s offering via the availability and price of skilled and } \\
\text { professional labour or the increased need to be close to } \\
\text { users/customers in knowledge-intensive sectors }\end{array}$ \\
\hline $\begin{array}{l}\text { Knowledge-based } \\
\text { perspective (Kogut \& } \\
\text { Zander, 1993) }\end{array}$ & Entry mode & $\begin{array}{l}\text { The entry mode depends on the knowledge content of the } \\
\text { transaction. FDI is made in order to collaborate with clients } \\
\text { and suppliers and control strategic knowledge. }\end{array}$ \\
\hline
\end{tabular}




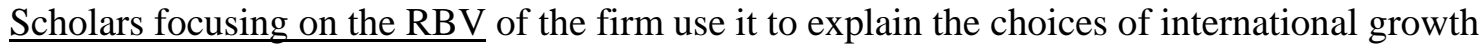
strategy (see e.g. Andersen \& Kheam, 1998; Peng, 2001). It has been argued that the speed, intensity and scope of internationalization are linked to the firm's resource endowments, which may include the international experience and skills of its managers, such as their ability to conduct market research or establish foreign operations (Buckley \& Casson, 2009). A lack of resources, such as limited knowledge of the foreign market, may slow down the process of internationalization (cf. the implicit link between the RBV and Johanson and Vahlne’s [1977] Uppsala model of internationalization). The entry mode could also be seen as a consequence of the resources a firm is able to mobilize, FDI being riskier and harder to finance than exports, and for that reason exporting is often the mode of choice among smaller, resource-constrained firms (see e.g. Buckley, 1989; Brouthers and Nakos, 2004). Following this line of thought, one could also explain the geographic scope of a firm's internationalization in terms of gradual growth and resource accumulation (Johanson \& Vahlne, 1977). For our quest, it is important to consider whether the born mMNEs' early commitment to the establishment of subsidiaries relates to the availability of slack resources - which may have been gained from the use of venture capital for example - or to learning.

There is a large body of empirical studies documenting the internationalization of firms at an early stage, such as is the case among BGs and INVs (Kuivalainen et al., 2007). Such studies illustrate how internationalization may be rapid and disruptive, and does not necessarily follow a slow, gradual path linked to the firm's resource accumulation (Cavusgil \& Knight, 2015). Drawing from the entrepreneurship literature, scholars point out that BGs and INVs tend to be founded and managed by highly skilled entrepreneurs (Nummela et al., 2004; Oviatt et al., 1995; McDougall \& Oviatt, 2000). Their skills, international experience and 
'global mindset' can help young and small firms overcome the liabilities of foreignness and smallness in spite of their limited resources (Oviatt \& McDougall, 1995; Zander, McDougallCovin \& Rose, 2015). Discussing mMNEs, Dimitratos et al. (2003) argue that the vision and expertise of the founder and top management help to explain the superior performance of these small, although not necessarily young, MNEs. Thus, scholars focusing on young exporters and small multinationals converge in pointing to the importance of the entrepreneur. Based on the existing BG and INV literature our presumption is that the mindset, skills and experience of the managers relate more to the speed and scope of internationalization and they may not explain the multinationalization, i.e. the establishment of subsidiaries in many cases.

Scholars focusing on the relational perspective (in other words, the network perspective) argue that firms invest across international borders in order to build closer relationships with their buyers and suppliers (cf. Gulati et al., 2000 and their network perspective in general). Some of the early literature on internationalization emphasized customer followership as a major reason for internationalization (Bell, 1995; Weinstein, 1977), meaning that the relationships the firm has determine the speed, entry mode and especially the location of its internationalization (Dyer and Singh, 1998). O'Farrell et al. (1998) argue that the first big client has a strong impact on market development. In some cases, following the customer could be seen as a reactive strategy with less emphasis on long-term planning, whereas in other cases it may be part of a broader strategic plan (Ciravegna et al., 2013; Eriksson, Majkgård \& Sharma, 2000). External resources, such as the network of relationships that firms develop, compensate for their resource constraints, helping them in their foreign market entries (Coviello, 2006; Ciravegna et al., 2013). Johanson and Vahlne’s (2009) revised Uppsala model emphasizes the role of these external resources, which combined with internal 
resources contribute to explaining internationalization. Networks provide opportunities and additional knowledge about the host market and, as mentioned above, help in defining the internationalization processes of small firms (Coviello \& Munro, 1997; McDougall \& Oviatt, 2000; Bresnahan, Gambardella \& Saxenian, 2001; Moen, Gavlen \& Endresen, 2004; Ojala, 2009). They are thus particularly important in influencing the 'when' (the speed), 'how' (the entry mode) and 'where' of the internationalization of young and small firms such as BGs, INVs and born mMNEs. However, the multinationalization part is often not explicitly considered from this perspective as the focus may have been on other operation modes, such as partnerships.

TCE provides a theoretical framework explaining internationalization in terms of the nature of transactions, the bounded rationality of decision makers and the risk of opportunistic behaviour (Williamson, 1985). Firms choose their entry mode in order to protect themselves from the risk of opportunism. They internalize transactions and engage in high-control entry modes (such as FDI) in circumstances in which the risk of opportunism is higher, whereas they choose to export when such risks are low (Rugman \& Verbeke, 2003). TCE also explains, at least to a certain extent, the location of the FDI: the company may choose a location that facilitates the minimization of transaction costs. One example of this so-called spatial cluster is the City of London and its financial sector (Dunning, 1998). According to our knowledge TCE has not been used to study mMNEs' entry mode choice in the past; however, the opportunity and risk aspects that relate to TCE have been studied to a certain extent. Dimitratos et al. (2014) found out that risk-taking propensity and networking increased the likelihood of firms to become mMNEs.

The OLI model (Aharoni, 1993; Dunning, 1993, 1998; Brouthers et al., 1996) is based on the premise that firms invest abroad to exploit firm-specific advantages that their home country 
does not offer, such as low-cost inputs (efficiency seeking), large markets for their products (market seeking) and co-operation partners (strategic-asset seeking). The co-existence of OLI advantages could eventually lead to FDI in a chosen foreign market. The OLI model thus explains the entry mode and location with regard to the characteristics of the host country as well as the specific business focus (the firm-specific advantages, see also Hennart [2009]) of the firm. Our assumption is that as born mMNEs use advanced market-servicing modes such as FDI by default, they commit to markets if one or several of the OLI conditions are fulfilled.

The knowledge-based perspective posits that the way in which a firm internationalizes may also depend on the knowledge content of its transactions (Kogut \& Zander, 1993). When the completion of the transaction requires the exchange of tacit knowledge, firms are likely to open subsidiaries and interact directly with their clients (Rugman et al., 2011). A small firm implementing a high-commitment market-servicing mode, and thus becoming a born mMNE, enjoys the benefits of being able to provide better customer service and collecting feedback on market conditions (Dimitratos et al., 2003; Lu \& Beamish, 2001; Prashantham, 2011; Dimitratos et al., 2014). Born mMNEs may have access to greater stocks of learning processes, routines and systems that collect, disseminate and use information for their international activities (Dimitratos et al., 2014), and consequently the knowledge-based perspective could serve to explain the existence of born mMNEs among the other streams of literature referred to above.

\section{METHODOLOGY}


Qualitative research methods are particularly useful when the aim is to develop new research agendas, explore new phenomena and find settings that are not examined in the existing literature (Eisenhardt, 1989). As discussed in the previous sections, thus far the literature on multinationals has not focused on young internationalizing firms, neither have studies of BGs and INVs focused on the high-commitment entry-mode elements of rapid internationalizers. We use a case-based method that utilizes inductive theory building (Eisenhardt, 1989; Welch, Piekkari, Plakoyiannaki \& Paavilainen-Mäntymäki, 2011) and our aim is to develop testable propositions. A case study is a potential method to induce new theory from empirical data (Eisenhardt, 1989; Welch et al., 2011). However, our method is not induction in its purest form as we first studied the literature in order to be able to develop theoretical 'building blocks' for our analysis and then linked our theoretical discussion to in-depth qualitative evidence collected through various methods from four case firms (Eisenhardt \& Graebner, 2007).

We used purposeful sampling (Patton, 1990) to study SMEs that had multinationalized in an accelerated manner. We set various eligibility criteria for the case firms. The firm had to have fewer than 250 employees, fulfilling the EU classification of an SME (OECD, 2008). Even though the term mMNE contains the word 'micro' in relation to the size of the firm, mMNEs are seen as SMEs (Dimitratos, 2015). The industry of the born mMNE was not a selection criterion per se and it is more likely that born mMNEs operate in sectors that offer intangible products or services, such as software, given that it is easier to produce intangible offerings across distances with the help of ICT technologies. We opted for studying Finnish born mMNEs given that Finland is a small and open economy, and the phenomenon of interest may be most prevalent in this kind of setting with its relatively few customers for example. To qualify as a born mMNE the firm had to have an FDI in another country, and given our 
interest in rapidly multinationalizing companies, we only chose firms that had established the FDI(s) in less than three years after their foundation (following the 'rapid' criterion that Knight et al. [2004] used in an earlier study).

We focused our data collection on tracking the multinationalization patterns of each case firm, starting from its foundation until the latest data-collection point. These patterns vary slightly. We have mapped the key events in the multinationalization process of the case companies (with FDIs being the key events) and provide timelines for each of our cases (in the Appendix). The key motives behind these entries are also presented and discussed (for the guidance of the process type of research, see Langley [1999]). We relied on multiple sources of evidence to allow data triangulation, as suggested by Yin (1994), and used primary semistructured interviews with key informants and secondary sources. We conducted interviews with the CEOs of the companies, half of them being the original founders and the other half having a long history of working for the firm. We also interviewed the managers responsible for the subsidiaries, or other key employees of the subsidiary, in order to acquire a more holistic understanding of the multinationalization process. There was an average of four primary data-collection points for each case firm. The interviews were recorded and transcribed, and stored in a case database. The firms' websites and search engines were used to find secondary data: all press releases, news articles and other material related to the international expansion of each case firm was stored in the case database.

Table II: Data-collection points 


\begin{tabular}{|l|l|l|l|l|}
\hline & Alpha & Beta & Gamma & Delta \\
\hline CEO & 2011, 2014 & 2006, 2010 & 2004, 2006, 2010, & 2012, 2013, 2014 \\
& & & 2014 & \\
\hline $\begin{array}{l}\text { Subsidiary manager } \\
\text { / other key member }\end{array}$ & 2010,2015 & 2004 & 2011,2014 & 2015 \\
\hline
\end{tabular}

After the data collection we followed the suggestions of Eisenhardt (1989) and carried out a within-case analysis, writing detailed descriptions of each case and combining all the relevant information from the multiple sources of evidence. Thus, each case was first studied as a stand-alone entity. For example, by triangulating between the primary and secondary sources, we constructed timelines for each case firm's expansion to international markets. This allowed the unique pattern of each to emerge before we attempted to generalize them. We then conducted a cross-case search for patterns (Eisenhardt \& Graebner, 2007), using tables and graphs (e.g. Table I, which contains the theoretical building blocks) to facilitate the analyses (Miles \& Huberman, 1994). We used categories that had emerged from the literature to develop a framework for the cross-case analysis. These figures and tables, and this framework enabled us to identify differences and similarities between the cases. Finally, we followed an iterative process of moving between the literature and the case data to refine our findings, relate them to existing theories and clarify our contributions.

We took several measures to address the validity of our study. Eisenhardt (1989) notes that theory induced from data is likely to be valid as it mirrors reality. Our longitudinal data collection (Table II) allowed us to keep track of the case firms for several years, reducing the potential disadvantages associated with retrospective designs, such as recall problems. In addition to this, we triangulated between primary and secondary data sources, and used multiple informants in each firm to ensure the validity of the findings. The informants (at 
least one of the company representatives) were also asked to comment on the brief case summaries in order to validate our understanding of the cases.

\section{Findings and discussion}

\subsection{Case profiles}

We introduce the case companies in this section (see Table III in the text and Figures II-V in the Appendix) and in the following section we discuss the ways in which they multinationalized, illustrating common patterns and themes (Table IV).

Table III: Four Finnish born mMNEs

\begin{tabular}{|c|c|c|c|c|}
\hline & Alpha & Beta & Gamma & Delta \\
\hline Year of foundation & 1997 & 2000 & $2000^{1}$ & 2012 \\
\hline No. of employees ${ }^{2}$ & 35 & 191 & 120 & 8 \\
\hline Average annual sales ${ }^{3}$ & Approx. €3.5 m & Approx. €58.2 m & Approx. €10.1 m & $\begin{array}{l}\text { (piloting with both } \\
\text { domestic and foreign } \\
\text { customers) }\end{array}$ \\
\hline $\begin{array}{l}\text { The nationality of the } \\
\text { founders }\end{array}$ & Finnish & Finnish & Finnish & Finnish and Polish \\
\hline The type of product & $\begin{array}{l}\text { Benchmarking } \\
\text { software (computer } \\
\text { hardware } \\
\text { performance) }\end{array}$ & $\begin{array}{l}\text { Electronic patient } \\
\text { diaries and } \\
\text { wireless data } \\
\text { solutions for } \\
\text { clinical trials }\end{array}$ & $\begin{array}{l}\text { Data-erasure and } \\
\text { computer-reuse } \\
\text { solutions }\end{array}$ & $\begin{array}{l}\text { An app (and solution } \\
\text { for B2B customers) } \\
\text { for sharing TV clips } \\
\text { on social media }\end{array}$ \\
\hline $\begin{array}{l}\text { First foreign market } \\
\text { entry }\end{array}$ & 1997 & 2000 & 2000 & 2013 \\
\hline First FDI & 2000 & 2000 & 2002 & $2014^{5}$ \\
\hline No. of foreign offices & 2 & 2 & 15 & $2^{6}$ \\
\hline \multicolumn{5}{|c|}{1 1997-2000; some operations occurred under a different name and business model. } \\
\hline \multicolumn{5}{|c|}{2 In 2014, except for Beta in 2013.} \\
\hline \multicolumn{5}{|c|}{3 In 2013 (last publicly available information). } \\
\hline \multicolumn{5}{|c|}{4 Pilot customers in two countries, operations in three (incl. e.g. HQ, sales and R\&D in different locations). } \\
\hline \multicolumn{5}{|c|}{5 Employees in Poland and UK since 2013; the first 'physical' FDI came when an office was established in Poland in 2014.} \\
\hline
\end{tabular}


Case firm Alpha, founded in 1997, is a software company that creates benchmarks enabling people to measure, understand and manage the performance of computer hardware. Most of Alpha's revenue comes from its B2B clients in the US and Taiwan, but small streams also come from B2C customers. The timeline of Alpha's key internationalization events are presented in Figure II in the Appendix. Its internationalization already started with exporting in 1997 and its multinatinalization (the opening of its first subsidiaries in the US and Canada) took place in 2000. There were several motives behind the entries. Alpha decided to settle in the US to develop its solution together with its key customers, all of whom resided close by in Silicon Valley. Market potential and personal reasons can also be noticed as reasons behind entries. For example, the VP for marketing recalls 'One of our VPs travelled a huge amount to China and then we decided to open an office there in 2008 to handle what we thought would be a good place for both sales and extra engineering'. The company set up its subsidiaries as greenfield investments but also used a partner in Taiwan before replacing the partner company with its own workforce in 2012. The contract with the Taiwanese partner was terminated upon finding some accounting irregularities. This made the company decide to change the operation mode and hire a full-time sales person in Taiwan. Their VP for marketing stated:

I could write a full $\mathrm{PhD}$ thesis just on how to hire and maintain the right people in Far Eastern subsidiaries ... but it can be summed up as "Find good people who are already known by a personal friend. Give them full responsibility to handle the business on their own. Provide them with the right resources to get their job done. Visit only when they ask, not when you feel like a trip to eat dumplings” By the way... that formula works around the world'. 
The company has stayed rather small over the years. A key reason for this is that they have over the years - sold some of their operations that were not seen as core for their business. For example, gaming operations were sold to another Finnish company and a Chinese subsidiary was sold to the mobile benchmarking arm that spun off from Alpha.

Case firm Beta, founded in 2000, is a provider of electronic patient diaries and wireless datacollection solutions that are used for data capture in clinical trials. The rapid international expansion was seen as a key target from day one and the founders wanted to create a global firm. Beta has subsidiaries that were set up as greenfield investments (see Figure III in the Appendix). The first sales subsidiary in the US was established within the very same year the company was founded. The key reason behind the market entries was the idea to be near clients. Their client targets were the top 10 pharmaceutical companies, all of which operate globally. As Beta was providing disruptive technology for the value chain of the pharmaceutical industry, two key reasons for the greenfield FDIs can be found. First, the management felt that they needed to educate potential customers and this would be easier when in their close vicinity, and second, there were no possible middlemen easily available as they were more or less establishing the industry and destroying the business of old, nondigital clinical trial companies. Eventually, after learning how the market worked, they closed some of the offices (e.g. in Germany and the Czech Republic) - the management of Beta had come to the conclusion that even though many pharmaceutical companies have operations in many countries, their decision-making is rather centralized and it would be more beneficial for Beta to concentrate its resources in the locations where the headquarters of the customers are. In this the subsidiary in the US was found to be seminal as it was near a cluster of the headquarters of its key clients and eventually the company moved its headquarters to the US in 2004. Recruitment policy for the US office meant that most of top management team 
members were US-based only five years after the foundation of the company. This enabled the company to learn rapidly about the markets and become embedded in local networks. The UK office's role was defined as that of a hub for sales and distribution in Europe, and R\&D was kept mostly in Finland. Currently the only Finnish top management team member is the Chief Technology Officer. For a number of years Beta’s organizational structure has been very similar and the company seems to operate as an mMNE with core employees located in two continents and possessing customers all over the world.

Case firm Gamma, founded in 2000, provides data-erasure and computer-reuse solutions that ensure the complete and secure cleaning of hard disks. Gamma has changed its international operational mode several times (see Figure IV in the Appendix). First it served international markets via direct sales from headquarters. Second, it started to build a global network of partners. Often the trigger for entry to a new market was an unsolicited export order. However, it also opened its first subsidiaries in 2002 in order to be able to have more control of its international operations. There were multiple reasons behind FDIs and, in the case of the Australian subsidiary, the CEO and co-founder also pointed out personal motivations to visit the country. Third, the company wanted to improve the efficiency of its partners and introduced a franchising model. Fourth, from approximately 2009 onwards Gamma started acquiring the shares of its partner companies and also made new greenfield investments by establishing new subsidiaries; it revised its operations in the UK and the US. A key motivation for the new operation model, which was more controlled and centralized, was to serve customers better with a more integrated value chain as low-end competition had started to appear and the company wanted to make its value proposition clearer for its current and potential customers. Interestingly, for a number of years Gamma was using multiple 
operation modes in parallel. This type of behaviour is typical for many MNEs (Benito et al., 2009) but has been less studied in an INV/BG setting in the past.

Case firm Delta, founded in 2012, provides an application that allows smartphone and tablet users to access a replay of an interesting moment they saw on a TV show and share that on social media. The company's revenue comes from corporate customers, such as TV channels, and the end users can use the application without charge. It has been able to pilot its service with four TV channels (in Finland, Poland and Spain) and has developed the service based on the lessons learned from end users and TV channels. The founding team of Delta knew each other from their previous work experience in a large multinational company but had different cultural backgrounds and experience. Hence, operations first spread around Europe in order to benefit from operating in multiple locations and for personal reasons (see Figure V). An example of a personal reason is that the partner of one of the founders received a good job offer from the UK - this provided an additional incentive to locate activities in the UK. Delta currently operates in the UK and Poland, in addition to Finland, enabling it to work closely with potential clients in the UK, as the UK is seen as a hub for all European TV business, and to utilize an affordable workforce for its R\&D and product development (in Poland). The company has migrated from home offices to 'proper' offices as the number of workers has increased. Other motives for establishing an office in Poland relate to the aim to be able to work more efficiently, facilitate communication and create and build organizational culture for example.

\subsection{Cross-case analysis}


In this section we outline a cross-case analysis that is based on the findings of our study and includes the key aspects of multinationalization in born mMNEs (Table IV). We then present five propositions in which we incorporate our findings into the various theoretical frameworks on internationalization, and contrast our multinationalization cases with traditional models of internationalization.

Table IV: Multinationalization in born mMNEs - a cross-case comparison

\begin{tabular}{|c|c|c|c|c|}
\hline & Alpha & Beta & Gamma & Delta \\
\hline Market selection & 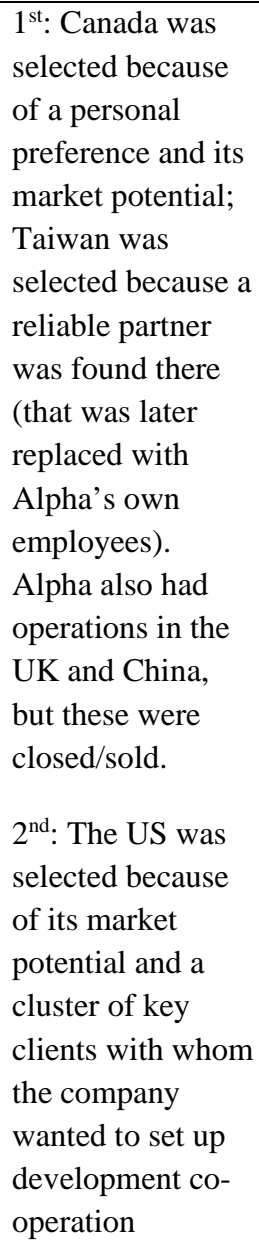 & $\begin{array}{l}1^{\text {st }} \text { European markets } \\
\text { (Sweden, Germany, } \\
\text { Czech Republic) were } \\
\text { selected because of } \\
\text { the lower psychic } \\
\text { distance } \\
2^{\text {nd. The US was }} \\
\text { selected based on its } \\
\text { market potential and } \\
\text { the presence of key } \\
\text { global actors with } \\
\text { whom to collaborate }\end{array}$ & $\begin{array}{l}1^{\text {st: Markets were }} \\
\text { selected reacting } \\
\text { to unsolicited } \\
\text { orders and } \\
\text { following a large } \\
\text { client in new } \\
\text { markets } \\
2^{\text {nd: A focus on }} \\
\text { European markets } \\
\text { because of } \\
\text { resource } \\
\text { limitations and to } \\
\text { allow for the } \\
\text { further } \\
\text { customization of } \\
\text { the service to meet } \\
\text { local needs }\end{array}$ & $\begin{array}{l}\text { Markets were } \\
\text { selected reacting } \\
\text { to unsolicited } \\
\text { orders and } \\
\text { pursuing } \\
\text { opportunities } \\
\text { generated by the } \\
\text { founders' } \\
\text { networks }\end{array}$ \\
\hline Operation modes & $\begin{array}{l}1^{\text {st: }} \text { Operating via } \\
\text { wholly-owned } \\
\text { subsidiaries in } \\
\text { Canada and the } \\
\text { US, and a partner } \\
\text { company in }\end{array}$ & $\begin{array}{l}\text { Operating via wholly- } \\
\text { owned subsidiaries in } \\
\text { the US and the UK }\end{array}$ & $\begin{array}{l}\text { Operating using } \\
\text { different entry } \\
\text { modes over time: } \\
1^{\text {st }} \text { using direct } \\
\text { sales from HQ; } 2^{\text {nd }} \\
\text { using sales } \\
\text { through partners; }\end{array}$ & $\begin{array}{l}\text { Operating via a } \\
\text { wholly-owned } \\
\text { subsidiary in } \\
\text { Poland and an } \\
\text { employee in a } \\
\text { 'virtual office' } \\
\text { type of setting in }\end{array}$ \\
\hline
\end{tabular}




\begin{tabular}{|c|c|c|c|c|}
\hline & 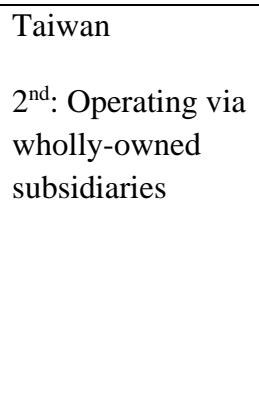 & & $\begin{array}{l}3^{\text {rd }} \text { using partners } \\
\text { working under a } \\
\text { franchising model; } \\
4^{\text {th }} \text { using wholly- } \\
\text { owned } \\
\text { subsidiaries in key } \\
\text { markets and a } \\
\text { global partner } \\
\text { network }\end{array}$ & the UK \\
\hline $\begin{array}{l}\text { Foreign sales as a } \\
\text { percentage of total } \\
\text { sales }\end{array}$ & $100 \%$ & $100 \%$ & $98 \%$ & - \\
\hline $\begin{array}{l}\text { International staff as } \\
\text { a percentage of total } \\
\text { staff }\end{array}$ & $27 \%$ & $92 \%$ & $71 \%$ & $88 \%$ \\
\hline $\begin{array}{l}\text { The number of } \\
\text { foreign-market } \\
\text { entries }\end{array}$ & 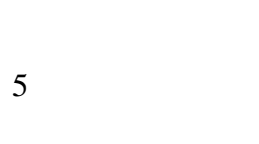 & 5 & 62 & 3 \\
\hline $\begin{array}{l}\text { De-/re- } \\
\text { internationalizations } \\
\text { during the process }\end{array}$ & $\begin{array}{l}\text { Withdrew from } \\
\text { three markets (one } \\
\text { office closed) }\end{array}$ & $\begin{array}{l}\text { Withdrew from three } \\
\text { markets (closing the } \\
\text { offices in all of them) }\end{array}$ & $\begin{array}{l}\text { Withdrew from } 16 \\
\text { markets in which } \\
\text { it operated with } \\
\text { partners but later } \\
\text { re-entered them } \\
\text { with its own } \\
\text { offices / other } \\
\text { partners }\end{array}$ & $\begin{array}{l}\text { Withdrew from } \\
\text { one market (but } \\
\text { never had an } \\
\text { office there) }\end{array}$ \\
\hline Offices \& functions & $\begin{array}{l}\text { Finland: HQ and } \\
\text { R\&D } \\
\text { US: Sales, } \\
\text { marketing, } \\
\text { customer support }\end{array}$ & $\begin{array}{l}\text { Finland: HQ and } \\
\text { R\&D } \\
\text { US, UK: Sales, } \\
\text { marketing, customer } \\
\text { support }\end{array}$ & $\begin{array}{l}\text { Finland: HQ and } \\
\text { R\&D } \\
\text { UK, US, } \\
\text { Australia, Japan, } \\
\text { Canada, Italy, } \\
\text { Sweden, } \\
\text { Germany, France, } \\
\text { Spain, Mexico, } \\
\text { Netherlands, } \\
\text { Russia, Malaysia, } \\
\text { New Zealand: } \\
\text { Sales, marketing, }\end{array}$ & $\begin{array}{l}\text { Finland: HQ \& } \\
\text { customer support } \\
\text { Poland: R\&D \& } \\
\text { customer support } \\
\text { UK: sales, } \\
\text { business } \\
\text { development }\end{array}$ \\
\hline
\end{tabular}




\begin{tabular}{|l|l|l|l|l|}
\hline & & & customer support & \\
\hline
\end{tabular}

\subsection{Dimensions explaining the progress of the multinationalization process}

The beginning of the multinationalization process is related to the global mindset of the born mMNE’s management (Buckley \& Casson, 2009; Nummela et al., 2004; Oviatt et al., 1995), the OLI model (Aharoni, 1993; Dunning, 1993, 1998; Brouthers et al., 1996) and relational IB theory (Gulati et al., 2000). These views explain why the firm becomes a born mMNE instead an exporting company for example. The importance of having a global mindset is highlighted in several studies as a variable affecting the speed, intensity and scope of internationalization, including the extent to which the firms are prepared to invest abroad and thus become multinationals (Buckley \& Casson, 2009; Nummela et al., 2004; Oviatt et al., 1995). Our cases opted for FDI because one or more OLI conditions (Aharoni, 1993; Dunning, 1993, 1998; Brouthers et al., 1996) were fulfilled. All the cases were marketseeking organizations at first because of the small size of their home markets, and one also sought strategic assets and efficiency. Our cases went to markets in which their key customers and co-operation partners resided and where they could leverage low-cost labour. It is particularly useful for technology providers to be inside technology hubs. All in all, international markets were perceived as sources of multiple opportunities that were not available at home: strategic clients, potential co-operation partners and specialized skills. Relational IB theory (Gulati et al., 2000) and the knowledge perspective (Kogut \& Zander, 1993) also explain the FDIs of born mMNEs. Having a physical presence in their key markets was important for marketing and customer-relationship reasons in all the case firms. Alpha and Beta opened subsidiaries to acquire credibility and to co-operate more closely with their key clients. Gamma also needed credibility and input for product development, in addition to 
local market information. Delta wanted to exploit the founders’ international networks and low-cost labour. All the case companies obtained the majority of their revenue from businessto-business sales, meaning that their customers were fewer in number and more geographically focused. Equally consistent with the relational perspective was that another major reason for investing abroad (as opposed to only exporting to multiple markets) was to provide customer support and maintain relationships with key clients (Gulati et al., 2000): 'Our customers expect us to operate in many markets because they do too. They expect to get customer support in Japanese from a local office in Japan.' (Founder and CEO, Gamma).

Relational capital is important in ensuring client satisfaction and repeated purchases (Hitt, Bierman, Uhlenbruck \& Shimizu, 2006; Lovelock, 1999):

If it [maintaining the customer relationship] is done via email, it very easily leads to misunderstandings; the customer thinking that we don't understand them. (...) In conflict situations it is very important that we express that we understand the customer's distress. It is so much easier to express that when you are present. (CEO, Alpha)

Developing relationships with strategic clients is another key factor explaining when, how and where such firms internationalize and it is consistent with the relational perspective of internationalization. Finally, there is a more conventional reason for going multinational and opening subsidiaries - visibility and reputation. We noted that both the BG/INV literature and MNE theories explain the beginning of the multinationalization process of our born mMNEs. All of our cases support the market-seeking approach of the OLI model, and some of them 
multinationalized to exploit strategic assets and location advantages. However, given the predominance of market-seeking reasons, we propose the following:

P1. Born mMNEs mainly multinationalize from inception for market-seeking reasons; to be near their key clients and co-operation partners, and to acquire visibility and a good reputation among them.

The continuing process of multinationalization of our born mMNEs could be characterized as the entrepreneurial seizing of opportunities (Ciravegna et al., 2013). Alpha first selected its markets on the basis of personal preferences and market potential, and Beta because of the lower psychic distance, but both soon opted for a location near their key clients and cooperation partners. Gamma reacted to unsolicited orders and followed its clients but later on realized that it needed to focus more on market selection because of resource constraints. Delta reacted to unsolicited orders and opportunities that arose from the founders' networks. This is in line with the BG/INV literature that highlights reactions to unsolicited orders and the opportunities provided by networks (Jones, 1999; McDougall \& Oviatt, 2000; Shrader et al., 2000; Bell et al., 2004; Coviello, 2006; Kuivalainen et al., 2007; Lopez et al., 2008). In many cases certain markets are only selected in order to follow a large client and certain markets are selected because there is customer potential (Bell, 1995; Weinstein, 1977). However, it seems that even though the case companies followed this route in their initial market selection, they adopted a more strategically planned approach later on, and some of them closed their offices and withdrew from markets they had selected because of opportunities rather than because of a strategic plan.

Having all the software development in Poland halves our development expenses compared to having the same work done in Finland. Also, in Poland we have better 
access to local talent, and it would be difficult to hire experienced coders here [in Finland], while in Poland it's easy for two reasons: our co-founders know people from there and in Poland the salaries we can pay are competitive. (Founder and CEO, Delta)

In some situations it may be that reactive, opportunistic reasoning coexists with strategic proactive decision making, but when the role and responsibilities of the international operations increase, the more systematic approach becomes more dominant. For example, after the first, market-seeking and reputation-seeking phases the subsidiaries in all the cases took on a different function - working closely with strategic clients and partners to exchange tacit knowledge and to customize the offering (Kogut \& Zander, 1993).

With our pioneer customers, we do things together. For example, in Japan we have developed totally new technologies; in the US we have tried different delivery channels; and in Scandinavia, some new business models. (Founder and CEO, Gamma)

Knowledge content thus explains the need to be physically close to key clients, and many born mMNEs multinationalize by establishing a presence in so-called strategic markets in order to provide their customers with a superior customer service and to work on and develop new products in close co-operation with them. We therefore propose the following:

P2. Both opportunities and strategic factors affect born mMNEs' multinationalization - they follow opportunities but establishing a presence in strategic markets is more important for 
them and they move towards this strategic approach as they proceed in their multinationalization.

The process of multinationalization has also meant using a hybrid combination of entry modes. Born mMNEs invest, disinvest and change governance in their subsidiaries much more rapidly than other firms. Alpha had wholly-owned subsidiaries from the beginning and complemented this approach with one partner company, which was later replaced by their own workforce. Beta only had wholly-owned subsidiaries from the very beginning. Gamma proceeded from selling directly from headquarters to conducting sales through partners, then selling to partners working under a franchising model and finally to having wholly-owned subsidiaries in key markets and a global partner network to service less important markets. Delta's employees outside their home country used their homes as offices and the company operated almost like a virtual office despite having physical headquarters in the home country. The company established its first physical subsidiary in Poland in 2014, which was a significant commitment for the start-up. All of these firms opted for opening their own offices less than three years after their inception. Their proceeding to higher-commitment market-servicing modes was faster than predicted, even by the literature on BGs (Hashai \& Almor, 2004). The key reason behind FDI decisions was the ability to serve clients better. Working closely with clients is often a means to fully developing the offering and customizing it to the market, and although this could be achieved through virtual meetings, such as Skype calls, a physical presence and face-to-face interactions play a crucial role. The local presence was in many cases seen as fundamental for success. For example, in Alpha the cannibalization of the existing value chain would have been difficult without their presence in the key market (the USA). One of the founders noted that the 'industry was not ready for partnerships as service providers were afraid of losing their margins to new technologies.' In 
addition to the 'softer' reasons for wanting to be near their clients, born mMNEs also want to have control, in line with TCE (Rugman \& Verbeke, 2003), and thus opted for their own subsidiaries instead of joint ventures and resellers. Interestingly, personal motives also came through in the interviews in case of Alpha, Gamma and Delta. In the case of Delta, for example, family reasons affected the decision to establish an office in London. Therefore we propose the following:

P3. The operation mode of born mMNEs reflects the need to serve clients and the level of control they wish to exercise on operations established in new markets. They also change governance structures as necessary in their search for the optimal solution. However, personal reasons may also affect the choice of higher-commitment market-servicing modes.

\subsection{Born mMNEs: multinationalization, not just internationalization}

Born mMNEs are rapidly multinationalizing (as opposed to merely rapidly internationalizing) firms. Our cases spread their value-adding functions among multiple locations and also generate a significant amount of their revenue from international markets. They soon began to target international markets, often from their inception. However, unlike the BGs currently depicted in most empirical studies, they also rapidly transformed into multinational enterprises, investing in multiple countries for different reasons. Born mMNEs challenge the RBV (Buckley \& Casson, 2009; Rugman et al., 2011; Peng, 2001) in that as young and small firms they should not have the resources to commit to FDI. However, they may still be able to establish FDI rapidly given the global mindset and often also given the previous experience of their founders, and they can compensate for their lack of experience by hiring local employees who have knowledge of certain market areas and connections with local networks. They can also afford FDI in that they produce intangible offerings and benefit from how working culture (hot desking, virtual offices) and technology have developed, allowing 
practically cost-free work coordination and communication (e.g. Loane, McNaughton \& Bell, 2004): all this facilitates the establishment of a born mMNE. On the other hand, born mMNEs diverge from the stream of literature focusing on BGs/INVs (Jones, 1999; McDougall \& Oviatt, 2000; Shrader et al., 2000; Bell et al., 2004; Kuivalainen et al., 2007; Lopez et al., 2008) because, as rapid internationalizers they are more likely to export and to rely mostly on unsolicited orders and networks in their choice of location. However, their customer relationships strongly affect their choice of entry mode and location. Born mMNEs with B2B offerings have fewer and larger customers and the main reason for making FDIs is to co-create value and cultivate customer relationships, thus exporting is not an option that fulfils these requirements. Born mMNEs specifically target the locations in which their customers operate and thereby take more of a strategic, rather than opportunistic, approach in their international expansion.

P4. Born mMNEs are able to overcome resource constraints and establish FDI while young and small because of changes in working culture and technological developments.

Delta, the youngest of the four case firms, has multinationalized most rapidly. This may be explained by the changes that technology has brought to day-to-day work. It has been easier to operate as a multinational company in 2012 than in 1997, during which time the oldest case firm (Alpha) was established. Developments in technology may make the process of multinationalization even faster in the future. This means that we argue that it is necessary to go beyond the BG/INV and network literature and combine it with MNE theories to explain the rapid multinationalization of small firms, which manifests a combination of the aggressive and entrepreneurial behaviour of BGs/INVs. BG/INV and network literature can explain the speed, but MNE theories, such as the OLI model, explain the choice of a highcommitment operational mode and the knowledge perspective explains the locations in which 
they are more likely to access strategic resources. However, MNE theories alone lack the power to explain entrepreneurial and agile behaviour in accelerated multinationalization and both viewpoints are needed. We therefore propose the following:

P5. Born mMNEs combine the internationalization speed, scale and scope of BGs/INVs with MNEs' high commitment to the chosen international markets while remaining small in size.

\section{CONCLUSIONS}

\subsection{The multinationalization process of born mMNEs}

We focused in the previous sections on the dimensions of multinationalization we found to be the most important and tried to build explanations as to why the various events in the process of multinationalizing in born mMNEs happened over time. In conclusion, we suggest that a modified version of the Uppsala model of the internationalization process would best serve to illustrate this process. The right-hand boxes of our framework in Figure 6 (which is modified from Vahlne et al. [2012]) identify the sub-processes that constitute the multinationalization process of born mMNEs. These are the factors that mark the changes in the company during the process. The upper box represents commitment decisions such as the opening of new offices and extending the value-adding activities to them: the commitment decision may also be reversed or negative, such as closing an office in a certain market area. The box also covers the reconfiguration of the value chain, such as locating various company functions at the subsidiaries instead of the domestic headquarters. As soon as born mMNEs establish the FDI location, they give it a significant role in the value chain. This may stem from the locational advantage. For example, in Alpha and Beta and Gamma it was possible to recruit experienced and talented people into the foreign subsidiaries (cf. P4) and often (some) global responsibility and top management tasks were actually moved from Finnish headquarters to 
foreign subsidiaries. These kinds of recruits would have been difficult to make if the new personnel had needed to move to Finland. Furthermore, the focus on key markets and customers drives the commitment decisions (cf. P1). The lower box refers to the process for developing new knowledge by learning and creating, in this case mostly from internal sources such as the focal subsidiary or subsidiaries working closely with clients on both improving their offering and customizing it. Of special interest in this context is knowledge about subsidiary activities and resources. The subsidiary of the born mMNE should be able to provide more information and develop more competences when it is locally embedded (e.g. Andersson et al., 2001), and this should eventually speed up the multinationalization process. In a number of our case companies global marketing responsibility was actually moved to the subsidiary close to key customers. This required trust between the old and new members of the management, residing in offices in different countries. Trust building is a prerequisite for efficient learning and creation, as well as for any commitment decisions. In some of our case companies trust was built through rather traditional methods, e.g. in Gamma the managing director of the French subsidiary had learnt to know the company as a trainee during his exchange studies abroad, and in the case of the UK subsidiary a new managing director was recruited from a business partner. However, we have to note that in many companies the companies had made unsuccessful recruitments in the first place. Fortunately for them they were able to make fast changes, for example in Beta the whole US sales team were changed within a year, and new recruits were brought in (cf. P5 and 'aggressive behaviour'). Beta was able to develop the 'first class team' in the US eventually, and the organizational culture was transferred by one of the founders moving to the US one year with the other founder spending half of his time in the US for a year and half. With this activity the company was able to develop both the internal and external network position of the US subsidiary. The left-hand boxes in Figure 6 are snapshots from any moment in time: born mMNEs possess a stock of 
knowledge about the markets and their international offices and have a certain position in relation to external and internal operators in the specific market area. Global opportunities and an entrepreneurial mindset make born mMNEs begin internationalization (cf. P1). Also the internal position of units in mMNEs may evolve rapidly over time - in the case of Beta the US subsidiary eventually became the headquarters of the whole company within four years (cf. P3).

Figure 6. The multinationalization process of born mMNEs (modified from Vahlne et al., 2012)

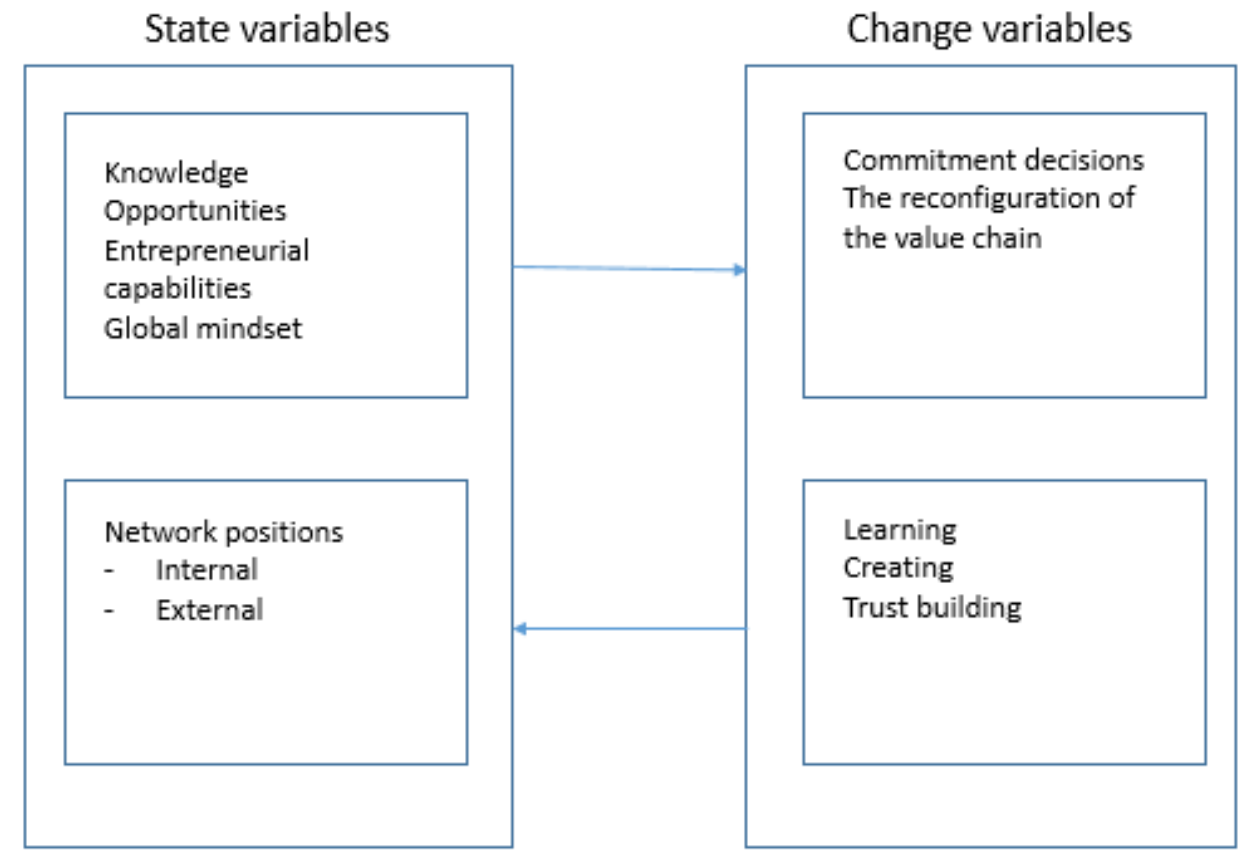

As a conclusion we suggest that the multinationalization process of born mMNEs consists of commitment decisions; reconfigurations of the value chain; and learning from, and creating and building trust with internal sources. 


\subsection{Limitations and further research directions}

This study possesses some limitations that may guide further research. First, as in any qualitative study, there are limitations related to narrow sampling. Although we selected our longitudinal cases carefully we need to be cautious about analytical generalization. For Lincoln and Cuba (1985) generalizability is more about analyzing the ‘transferability’ of research findings and this very much makes the context transparent to a reader. Our cases may be context-sensitive; it may be that internationalization is quite different in 2012 than it was in 2000 for example. We believe, however, that our findings can be generalized, at least among firms such as those in software and digital services that provide products or services that are fast and easy to transfer across borders (meaning that fixed costs and barriers to entry are low). These types of firm may multinationalize rapidly because of the intangibility of their offering, which allows multinationalization without high investments in facilities and machinery. Our study also concentrated on firms selling mostly to B2B customers, which may affect the generalizability.

Second, we have refined the definition of born mMNEs in this paper and have formulated propositions regarding their multinationalization. Our approach has been holistic and we have tried to study the phenomenon from various perspectives. Here we have tried to consider the 'added value' of different streams of literature, following the approach taken by Coviello and McAuley (1999). We have to acknowledge, however, that this type of multiperspective approach means that the depth of analysis is thinner than in studies that are based on a single theoretical framework. Hence, we would encourage other researchers to test our propositions and born mMNEs' international behaviour in different contextual settings and also in different theoretical settings. For example, regarding the former idea, how does being based in a large economy such as the US affect internationalization? Do born mMNEs operating in 
the manufacturing industry multinationalize for similar reasons and follow similar processes as do those operating in digital services and software? How does being a provider of a B2C offering affect first the internationalization and then the multinationalization of born mMNEs? For the latter, one could for example test our propositions only by using the OLI model as a theoretical framework. Furthermore, the possible use of hybrid operation modes or mode bundles (see e.g. Benito et al., 2009) among born mMNEs should be studied. Even if FDIs dominated within our four cases, Gamma, for example, had used multiple modes in parallel and we need more studies focusing on this type of behaviour. There seem to be several sub-patterns in multinationalization, even though the general model could be the same for all. It would be interesting to study (and distinguish) all the patterns of multinationalization with a larger number of cases. It would also be interesting to compare the findings with the broader literature of entrepreneurship. Moreover, the disaggregated operations of born mMNEs require more investigation as organizing work in this type of company differs from BGs and INVs that have all their core activities and key executives in one location. How these companies operate is an interesting topic for future studies. In terms of methodology, future research could take several directions. In quantitative studies, event history studies would be interesting as these are rare in the field, as Welch and PaavilainenMäntymäki (2014) note. In the qualitative field, more studies utilizing process data and analysis is called for (Welch \& Paavilainen-Mäntymäki, 2014). All in all, this global phenomenon, which is growing in importance, provides numerous avenues for future research.

\section{REFERENCES}

Acedo, F., \& Jones, M. (2007). Speed of institutionalization and entrepreneurial cognition: insights and a comparison between international new ventures, exporters and domestic firms. Journal of World Business, 42(3): 236-252. 
Aharoni, Yair (1993). Ownerships, Networks and Coalitions. In: Aharoni, Y. (Ed.), Coalitions and competition: the globalization of professional business services. Routledge: New York, pp. 121-142.

Andersen, O., \& Buvik, A. (2002). Firms' internationalization and alternative approaches to the international customer/market selection. International Business Review, 11, 347-363. Andersen, O., \& L.S. Kheam, (1998). Resource-based theory and international growth strategies: an exploratory study. International Business Review, 7, 163-184.

Andersson, U. \& Forsgren, M. (1996) Control and embeddedness in multinational corporations. International Business Review, 5(5): 487-508.

Andersson, U., Forsgren, M., \& Holm, U. (2001) Subsidiary embeddedness and competence development in mncs - a multi-level analysis. Organization Studies, 22(6): 1013-1035.

Bell, J. (1995). The Internationalization of Small Computer Software Firms - A Further Challenge to "Stage" Theories. European Journal of Marketing, 29(8): 60-75.

Bell, J., Crick, D., \& Young, S. (2004). Small firm internationalisation and business strategy: an exploratory study of 'knowledge-intensive' and 'traditional' manufacturing firms in the UK. International Small Business Journal, 22(1): 23-56.

Benito, G. R., Petersen, B., \& Welch, L. S. (2009). Towards more realistic conceptualisations of foreign operation modes. Journal of International Business Studies, 40(9): 1455-1470.

Birkinshaw, J. \& Hood, N. (1998) Multinational subsidiary evolution: Capability and charter change in foreign-owned subsidiary companies. Academy of Management Review, 23(4): 773-795.

Bresnahan, T., Gambardella, A., \& Saxenian, A. (2001). 'Old economy’ inputs for 'new economy'outcomes: Cluster formation in the new Silicon Valleys. Industrial and corporate change, 10(4): 835-860.

Brouthers, K. D., Brouthers, L. E., \& Werner, S. (1996). Dunning's eclectic theory and the smaller firm: the impact of ownership and locational advantages on the choice of entrymodes in the computer software industry. International Business Review, 5(4): 377-394. Brouthers, K. and Hennart, J.M.A. (2007). Boundaries of the firm: Insights from international entry mode research. Journal of Management, 33(3), 395-425.

Brouthers, K.D., \& Nakos, G. (2004). SME Entry Mode Choice and Performance: A Transaction Cost Perspective', Entrepreneurship Theory and Practice, 28(3): 229-247. Buckley, P. (1989). Foreign direct investment by small and medium sized enterprises: The theoretical background. Small Business Economics, 1: 89-100.

Buckley, P. J., \& Casson, M. C. (2009). The internalisation theory of the multinational enterprise: A review of the progress of a research agenda after 30 years. Journal of International Business Studies, 40(9): 1563-1580.

Burgel, O. and Murray, G.C. (2000). The international market entry choices of start-up companies in high technology industries. Journal of International Marketing, 8(2), 33-62.

Cavusgil, S. T. (1984). International Marketing Research: Insights into Company Practices. Research in Marketing, 7, 261-288.

Cavusgil, S. T., \& Knight, G. (2015). The born global firm: An entrepreneurial and capabilities perspective on early and rapid internationalization. Journal of International Business Studies, 46(1), 3-16.

Child, C. and McGrath, R.G. (2001). Organizations unfettered: Organizational form in an information intensive economy. Academy of Management Journal, 44(6), 1135-1148. Ciravegna, L., Lopez, L., \& Kundu, S. (2013). Country of origin and network effects on internationalization: A comparative study of SMEs from an emerging and developed economy. Journal of Business Research. 
Contractor, F.J., Kumar, V., Kundu S.K. and Pedersen, T. (2010). Reconceptualizing the Firm in a World of Outsourcing and Offshoring: The Organizational and Geographical Relocation of High-Value Company Functions. Journal of Management Studies, 47, 8. Coviello, N. \& McAuley, A. (1999). Internationalisation and the smaller firm: A review of contemporary empirical research. Management International Review, 39(3): 223-256. Coviello, N. E., \& Martin, K. A. M. (1999). Internationalization of service SMEs: an integrated perspective from the engineering consulting sector. Journal of International Marketing, 42-66.

Coviello, N. E., \& Munro, H. J. (1997). Network relationships and the internationalisation process of small software firms. International Business Review, 6(4): 361-386.

Coviello, N. (2015). Re-thinking research on born globals. Journal of International Business Studies, 46(1), 17-26.

Coviello, N.E. (2006). The network dynamics of international new ventures. Journal of International Business Studies, 37(5): 713-731.

Dhanaraj, C. and Beamish, P. W. (2003). A Resource-Based Approach to the Study of Export Performance. Journal of Small Business Management, 41, 242-261.

Dimitratos, P: (2015) Micromultinationals. Keynote presentation at McGill International Entrepreneurship Conference. London, 27.8.2015.

Dimitratos, P., Amorós, J.E., Etchebarne M. S. \& Felzensztein, C. (2014) Micromultinational or not? International entrepreneurship, networking and learning effects. Journal of Business Research, 67: 908-915

Dimitratos, P., Johnson, J., Plakoyiannaki, E. \& Young, S. (2016) SME internationalization: How does the opportunity-based international entrepreneurial culture matter? International Business Review, forthcoming.

Dimitratos, P., Johnson J., Slow, J. \& Young S. (2003) Micromultinationals: New Types of Firms for the Global Competitive Landscape. European Management Journal, 21(2): 164174.

Dunning, J. H. (1988). The eclectic paradigm of international production: A restatement and some possible extension. Journal of International Business Studies, 19(1): 1-31. Dunning J.H. (1989). Multinational Enterprises And The Growth Of Services: Some conceptual and theoretical issues. The Service Industries Journal, 9(1): 5.

Dunning, J. H. (1993). The Internationalization of the Production of Services: Some General and Specific Explanations. In: Aharoni, Y. (Ed.), Coalitions and competition: the globalization of professional business services. Routledge: New York, pp. 79-101. Dunning, J. H. (1998). Location and the multinational enterprise: a neglected factor? Journal of International Business Studies, 29(1): 45-66.

Dunning, J.H. (2003). Multinational enterprises and the growth of services: some conceptual and theoretical issues. In: Dunning, J.H. (ed.), Transnational corporations in services. Routledge: London.

Dyer, J. H., \& Singh, H. (1998). The relational view: Cooperative strategy and sources of interorganizational competitive advantage. Academy of management review, 23(4), 660-679. Eisenhardt K.M. (1989). Building theories from case study research. The Academy of Management Review, 14(4): 532.

Eisenhardt, K.M \& Graebner, M. E. (2007). Theory building from cases: opportunities and challenges. Academy of Management Journal, 50(1): 25-32.

Eriksson, K., Majkgård, A. \& Sharma, D.D. (2000). Path Dependence and Knowledge Development in the Internationalization Process. Management international review, 40: 307328. 
Gulati, R., Nohria, N., \& Zaheer, A. (2000). Strategic networks. Strategic Management Journal, 21(3): 203-215.

Hashai, N. \& Almor, T. (2004). Gradually internationalizing 'born global' firms: an oxymoron? International Business Review, 13: 465-483.

Hennart, J-F.; Park, Y-R. (1994). Location, governance, and strategic determinants of Japanese manufacturing investment in the United States. Strategic Management Journal, 15(6): 419-436.

Hennart, J-F. (2009). Down with MNE-centric theories! Market entry and expansion as the bundling of MNE and local assets. Journal of International Business Studies, 40(9): 14321454.

Hitt, M. A., Bierman, L., Uhlenbruck, K., \& Shimizu, K. (2006). The importance of resources in the internationalization of professional service firms: The good, the bad, and the ugly.

Academy of Management Journal, 49(6): 1137-1157.

Ibeh, K., Johnson J., Dimitratos, P. \& Slow J. (2004). Micromultinationals: Some Preliminary Evidence on an Emergent 'Star' of the International Entrepreneurship Field. Journal of International Entrepreneurship, 2: 289-303.

Johanson, J. \& Vahlne, J-E. (1977). The Internationalization Process of the Firm: A Model of Knowledge Development and Increasing Foreign Market Commitment. Journal of International Business Studies, 8(1): 23-32.

Johanson, J. \& Vahlne, J-E. (2009). The Uppsala internationalization process model revisited: From liability of foreignness to liability of outsidership. Journal of International Business Studies, 40: 1411-1431.

Jones, M. (1999). The Internationalization of Small High-Technology Firms. Journal of International Marketing, 7(4), 15-41.

Jones, M., Coviello, N. \& Tang Y. (2011) International Entrepreneurship research (19892009): A domain ontology and thematic analysis. Journal of Business Venturing, 26(6): 632659.

Knight, G. G., Madsen, T. T. \& Servais, P. P. (2004). An Inquiry into Born-Global Firms in Europe and the USA, International Marketing Review, vol. 21, no. 6, p. 645.

Kogut, B. \& Zander, U. (1993). Knowledge of the firm and the evolutionary theory of the multinational corporation. Journal of International Business Studies, fourth quarter.

Kuivalainen, O., Sundqvist, S., \& Servais, P. (2007). Firms’ degree of born-globalness, international entrepreneurial orientation and export performance. Journal of World Business, 42(3): 253-267.

Kuivalainen, O., Saarenketo, S., \& Puumalainen K. (2012). Start-up patterns of internationalization: a framework and its application in the context of knowledge-intensive SMEs, European Management Journal, 30(4): 372-385.

Langley, A. (1999). Strategies for theorizing from process data, Academy of Management review, 24(4): 691-710.

Laufs, K. \& Schwens, C. (2014). Foreign market entry mode choice of small and mediumsized enterprises: A systematic review and future research agenda. International Business Review, 23: 1109-1126.

Lincoln, Y.S. \& Cuba, E.G. (1985). Naturalistic inquiry. Newbury Park, CA: Sage. Loane, S., McNaughton, R. \& Bell, J. (2004). The internationalization of Internet-enabled entrepreneurial firms: Evidence from Europe and North America. Canadian Journal of Administrative Sciences, 21(1): 79-96.

Lopez, L. E., Kundu, S. K., \& Ciravegna, L. (2008). Born global or born regional? Evidence from an exploratory study in the Costa Rican software industry. Journal of International Business Studies, 40(7): 1228-1238. 
Lovelock, C. H. (1999). Developing marketing strategies for transnational service operations. Journal of services marketing, 13(4/5): 278-295.

Lu, J.W. \& Beamish, P.W. (2006). SME internationalization and performance: Growth vs. profitability. Journal of International Entrepreneurship, 4: 27-48

Mathews, J.A. \& Zander, I. (2007). The international entrepreneurial dynamics of accelerated internationalization. Journal of International Business Studies, 38:387-403

McDougall, P.P.\& Oviatt, B.M. (1996). New venture internationalization, strategic change, and performance: a follow-up study. Journal of Business Venturing, 11 (1): 23-40.

McDougall, P.P., and Oviatt, B.M. (2000). International entrepreneurship: the intersection of two research paths. Academy of Management Journal, 43(5): 902-906.

Miles, M. B., \& Huberman, A. M. (1994). Qualitative data analysis: An expanded sourcebook (2nd ed.). Thousand Oaks, CA: Sage Publishing.

Moen, O., Gavlen, M., \& Endresen, I. (2004). Internationalization of small, computer

software firms: Entry forms and market selection. European Journal of Marketing, 38(9-10): 1236-1251.

Nummela, N., Saarenketo S., \& Puumalainen, K. (2004). A global mindset - A prerequisite for successful internationalization? Canadian Journal of Administrative Sciences, 21(1): 5164.

O'Farrell, P. N., \& Wood, P. A. (1994). International market selection by business service firms: Key conceptual and methodological issues. International Business Review, 3(3): 243261.

OECD. (2008). Definition of small and medium sized enterprises (SMEs) Available: http://stats.oecd.org/glossary/detail.asp?ID03123. Accessed October 10, 2010.

Ojala, A. (2009). Internationalization of knowledge-intensive SMEs: The role of network relationships in the entry to a psychically distant market. International Business Review, 18: 50-59.

Oviatt, B. M. \& McDougall, P. P. (1994). Toward a theory of international new ventures. Journal of International Business Studies, 25(1): 45-64.

Oviatt, B. M., McDougall, P. P., \& Loper, M. (1995). Global start-ups: Entrepreneurs on a worldwide stage [and executive commentary]. The Academy of Management Executive (1993-2005): 30-44.

Patton, M. (1990). Qualitative evaluation and research methods. pp. 169-186. Beverly Hills, CA: Sage.

Prashantham, S., \& Young, S. (2011). Post-Entry Speed of International New Ventures Entrepreneurship Theory and Practice, 35(2): 275-292.

Prashantham, S. (2011). Social Capital and Indian Micromultinationals. British Journal of Management, 22(1): 4-20.

Peng, M. (2001). The resource-based view and international business'. Journal of Management, 27: 803-829.

Ripollés, M., Blesa, A. and Monferrer, D. (2012). Factors enhancing the choice of higher resource commitment entry modes in international new ventures. International Business Review, 21, 648-666.

Rugman, A. M., \& Verbeke, A. (2003). Extending the theory of the multinational enterprises: internalization theory and strategic management perspectives. Journal of International Business Studies, 34(2): 125-137.

Rugman, A. M., Verbeke, A., \& Nguyen, P. C. Q. T. (2011). Fifty years of international business theory and beyond. Management International Review, 51(6): 755-786. 
Shrader, R. C., Oviatt, B. M., \& McDougall, P. P. (2000). How new ventures exploit tradeoffs among international risk factors: Lessons for the accelerated internationization of the 21st century. Academy of Management Journal, 43(6): 1227-1247.

Subramaniam, R. (2015). Micro-Multinationals, and how they will define our era.

Youngupstarts. Available: http://www.youngupstarts.com/2015/07/31/micro-multinationalsand-how-they-will-define-our-era/ Accessed August 4, 2015.

Vahlne, J-E., Ivarsson, I. \& Johanson, J. (2011). The tortuous road to globalization for Volvo's heavy truck business: Extending the scope of the Uppsala model. International Business Review, 20: 1-14.

Vahlne, J-E., Schweizer, R. \& Johanson, J. (2012). Overcoming the Liability of Outsidership-The Challenge of HQ of the Global Firm. Journal of International Management, 18: 224-232.

Van de Ven, A. \& Poole, S. (1995). Explaining development and change in organizations. Academy of Management Review, 20(3): 510-540.

Varian, H. (2011). Micromultinationals will run the world. Foreign Policy. Available: http://foreignpolicy.com/2011/08/15/micromultinationals-will-run-the-world/ Accessed August 4, 2015.

Weerawardena, J., Sullivan, G., Liesch, P.W. \& Knight, G. (2007). Conceptualizing accelerated internationalization in the born global firm: A dynamic capabilities perspective. Journal of World Business, 42:294-306.

Weinstein, A. K. (1977). Foreign investments by service firms: the case of multinational advertising agencies. Journal of International Business Studies, 83-91.

Welch, C. \& Paavilainen-Mäntymäki E. (2014). Putting Process (Back) In: Research on the Internationalization Process of the Firm. International Journal of Management Reviews, 16(1): 2-23.

Welch, C., Piekkari, R., Plakoyiannaki, E. \& Paavilainen-Mäntymäki, E. (2011). Theorising from case studies: Towards a pluralist future for international business research. Journal of International Business Studies, 42, 740-762.

Yin, R. (1994). Case study research: Design and methods (2nd ed.). Thousand Oaks, CA: Sage Publishing.

Zahra, S.A., Ireland, R.D., Hitt, M.A., (2000). International expansion by new venture firms: international diversity, mode of market entry, technological learning, and performance. Academy of Management Journal, 43(5): 925-950.

Zander, I., McDougall-Covin, P., \& Rose, E. L. (2015). Born globals and international business: Evolution of a field of research. Journal of International Business Studies, 46(1): 27-35. 
APPENDIX

Figure II. Alpha’s timeline

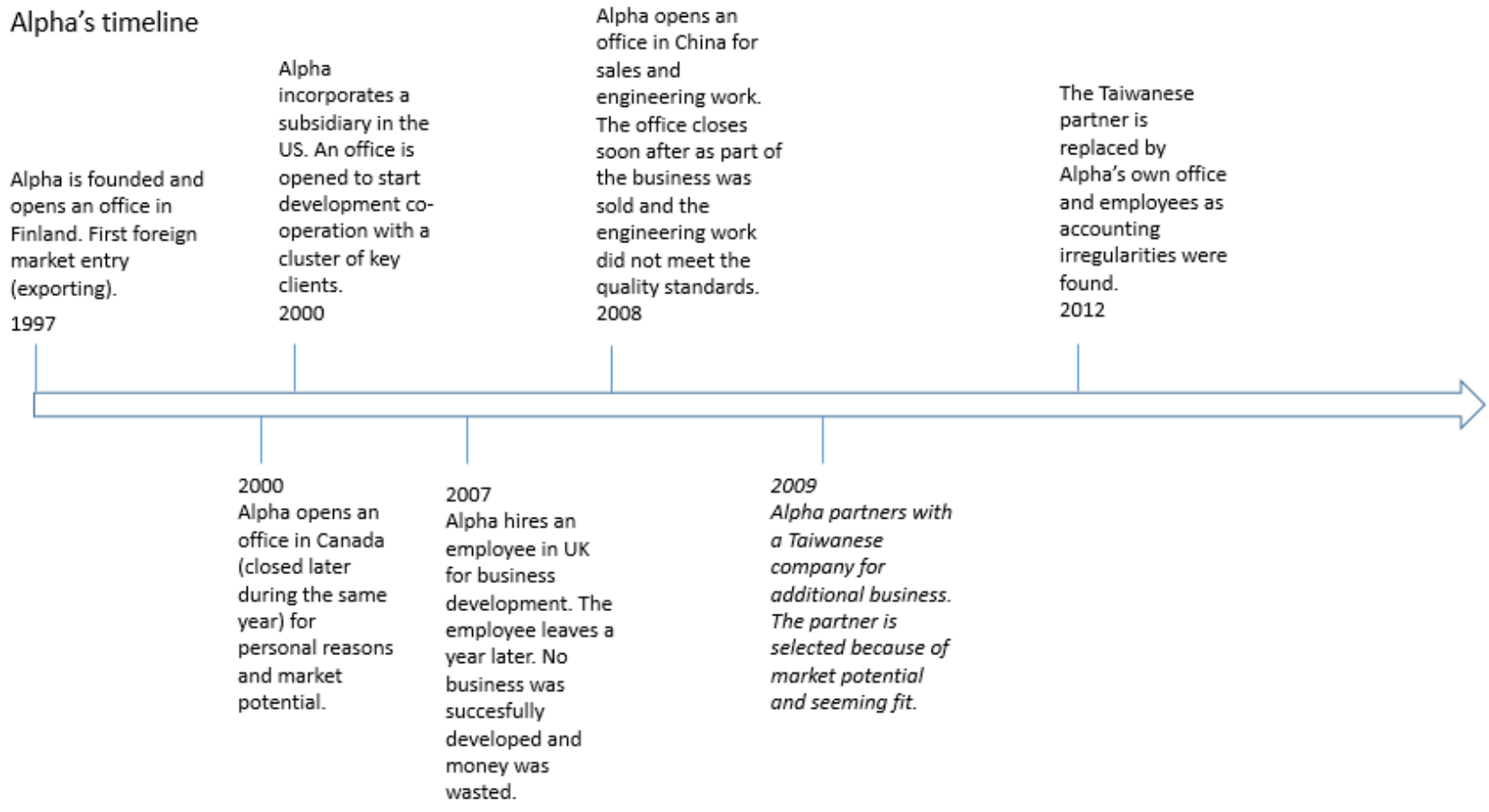


Figure III. Beta’s timeline

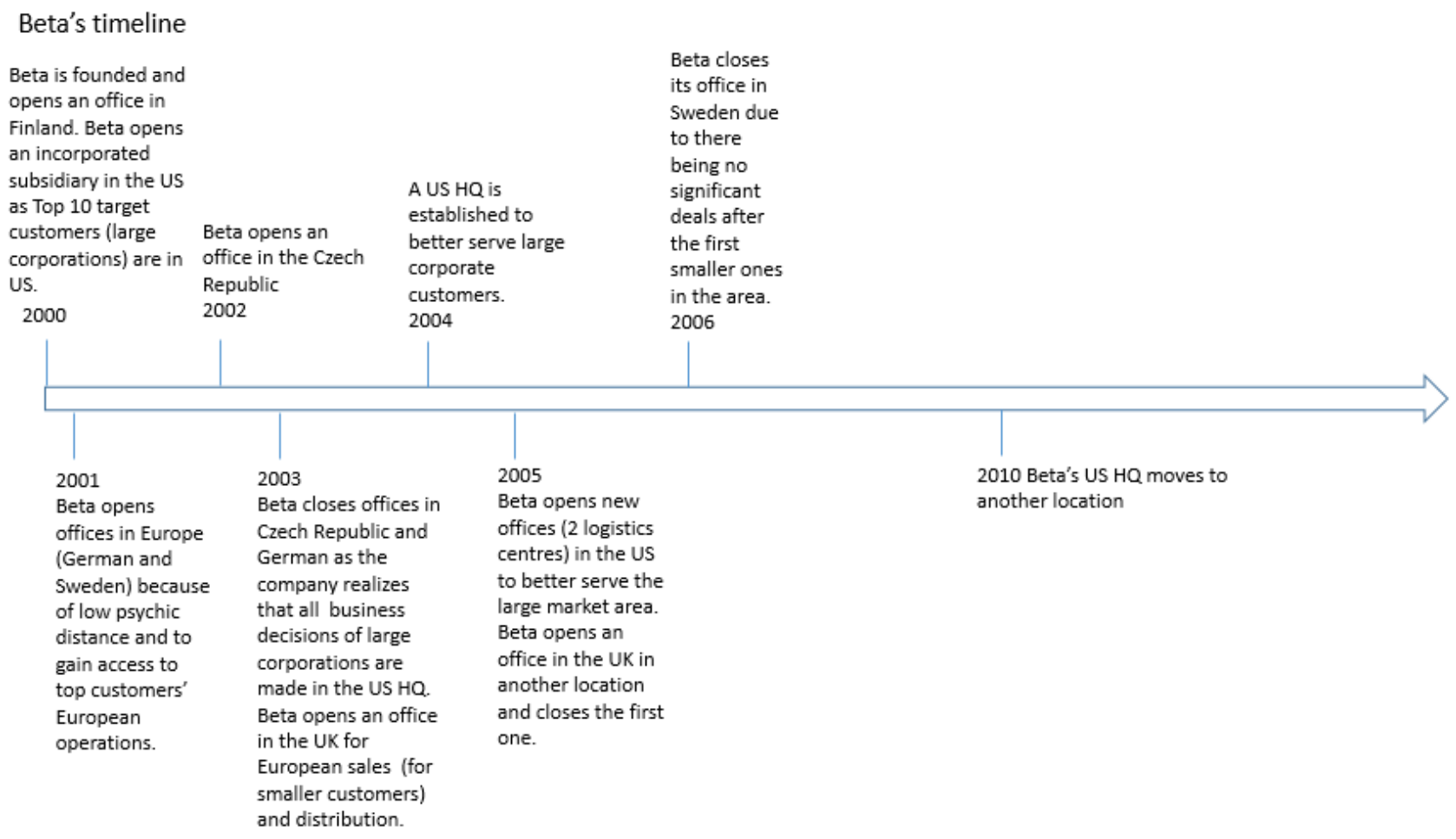

Figure IV. Gamma’s timeline

Gamma's timeline

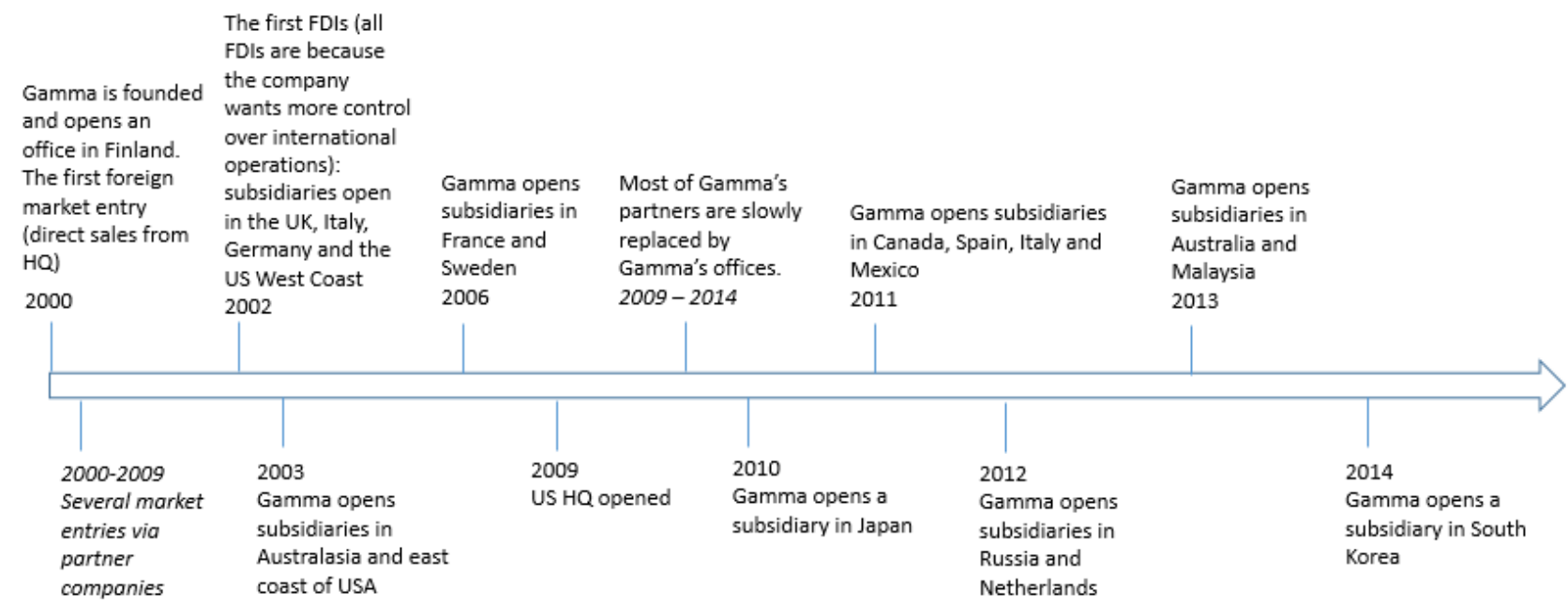


Figure V. Delta's timeline

\section{Delta's timeline}

Delta is founded and

opens an office in

Finland

Delta opens an

office in Poland to

facilitate work

efficiency,

communication

2012

and morale

2014

2013

Delta starts

operations and

recruits

employees in

Poland for cost

saving reasons

and in UK for

business

development and

sales reasons
2016

Delta opens an office in the

UK as a new CEO is hired in this location and to better

develop the business in this

TV business hub area. 